\title{
Effect of International Remittances on Inflation in Ghana Using the Bounds Testing Approach
}

\author{
Abdallah Abdul-Mumuni \\ Department of Banking and Finance, University of Professional Studies, Accra, Ghana \\ Tel: 233-509-363-799Ｅ-mail:aabdulmumuni@yahoo.co.uk
}

Christopher Quaidoo

Department of Banking and Finance, University of Professional Studies, Accra, Ghana

Received: November 30, 2015 Accepted: December 20, 2015

doi:10.5296/ber.v6i1.8635 URL: http://dx.doi.org/10.5296/ber.v6i1.8635

\begin{abstract}
This paper empirically examines the effect of international remittances on inflation in Ghana from 1979 to 2013 by incorporating international remittances as an exogenous variable to the standard inflation function. Applying the bounds testing approach, the empirical results indicate that international remittances have a significant effect on inflation in the long-run. However, in the short-run, no significant relationship is evident between these two variables. The study recommends that in order to reduce the effect of international remittances on inflation rate and increase the impact on growth, the government should improve public infrastructure. By this, excessive transfer fees would reduce and these remittances could be channeled into more productive sectors rather than being used mainly for consumption purposes.
\end{abstract}

Keywords: Remittances, Consumer Price Index, Money Supply, Trade Openness, Gross Domestic Product, Bounds Test, Ghana

\section{Introduction}

Even though human migration across national borders is not a new phenomenon, it is increasingly being recognized as an important factor in the current economic globalization scheme. With the rapid pace of globalization and from a symptom of development failure in migrants' home countries, the international movement of workers has come to be seen as a source of local development opportunity because of the money these migrants send home. It 
is estimated that over 200 million people in the world are currently living in a country in which they were not born, a number that is increasing each year (World Bank, 2014). Among these are millions of highly educated people who moved to developed countries from developing countries that already suffer from low levels of human capital and skilled workers. For instance, emigration from Ghana to Organization of Economic Co-operation and Development (OECD) countries, the Gulf States, as well as other fast-growing African economies has been fast, particularly when the Ghanaian economy experienced developmental challenges in the 1980s and 1990s (Gyimah- Brempong \& Asiedu, 2014). The primary purpose for this movement by Ghanaians to other countries has generally been economic; to look for better earning opportunities than are available in the migrants' home countries. Essentially, migrants earn higher incomes in the host countries and remit these incomes back home to be used for the improvement of household welfare. Some of these remittances are also put into productive investments which eventually lead to the growth of the economy. Thus, the prospects for emigration directly increase consumption and investment and this in turn, leads to the growth of the home country. Available statistics indicate that emigrants make about $7 \%$ of Ghana's population and the rates are particularly high among the educated. It is estimated that $47 \%$ of all tertiary education graduates from Ghanaian universities have emigrated (Ratha et al., 2011). Similarly, Clemens (2007) estimates that about $56 \%$ of physicians trained in Ghanaian medical schools have emigrated to OECD or the oil-rich Gulf countries.

As a result of increased emigration, the flow of international remittances from migrants to their relatives in their home countries has exhibited a rapid and accelerating rate of growth (Acosta et al.,2007).. In this regard, economists and policy makers are interested in the vast amount of remittances flowing from migrants' host to home countries. In most cases, these remittances flow from the developed to the developing and less developed countries. For instance, the World Bank estimates that migrants remitted about US $\$ 401$ billion to the developing countries in 2012 (World Bank, 2013). This figure is even considered to be lower than the actual figure as many migrants use informal mechanisms to send money. For most developing countries, remittances exceed the inflows of official foreign aid. In addition, they are considered a more stable source of money during financial crises (Ratha, 2007). Sander (2003), reports that remittances have proved to be the most stable flow compared to Overseas Development Aid (ODA) and other private capital flows.

In Ghana, there has been an increase in remittances from \$31 million in 1999 to \$138 million in 2013 (World Bank 2014). The increase in remittance flows to Ghana could be attributed to the liberalization of the foreign exchange market and the increase in the establishment of money transfer institutions. Currently, there are different transfer mechanisms available to migrants to send remittances to Ghana, namely, banks, credit unions, small and large money transfer institutions such as Western Union, MoneyGram and VIGO, hand delivery by the sender through a third party and other informal mechanisms (Quartey, 2006).

An increase in remittances flow into a country may lead to an improvement in household welfare and a growth of the economy. This notwithstanding, remittances flow into a country may also lead to some adverse effects on the economy. The negative effect of these 


\section{Macrothink}

Business and Economic Research

ISSN 2162-4860

2016, Vol. 6, No. 1

remittances on the receiving economy may occur in the form of reduced incentive for recipients to work and moral hazard problem. By increasing the supply of foreign exchange, remittances can cause the domestic currency to appreciate. This decreases the competitiveness of the traded goods sector leading to stagnation in the economy (Javaid, 2009). Additionally, remittances can cause inflation in the home country through the channel of aggregate demand. An increase in money supply through the inflow of remittances stimulates the demand for goods and services, and this consequently, increases the expenditure on consumer goods and services. The increase in aggregate demand puts upward pressure on prices and results in demand pull inflation (Iqbal \& Abdus ,2005; Nishat \& Nighat ,1991). High inflation increases the cost of business and thus discourages savings and investment. It also reduces consumption in general and affects the low and fixed income groups adversely by reducing their purchasing power. This undoubtedly leads to a high cost of living.

While research has shed some light on the potential influence of remittances on education (Brempong-Gyimah, 2014), Poverty (Quartey 2005), economic growth (Addison, 2004, Owiafe, 2008) and financial development in Ghana (Adenutsi, 2011), no attention has been given to the potential effect of these remittances on inflation. The objective of this paper is therefore to quantitatively investigate the effect of international remittances on inflation in Ghana using the bound testing approach. Incorporating international remittances in the inflation equation is relatively a new approach and the correct understanding of the influence of international remittances on a macroeconomic aggregate such as inflation is crucial for policy makers to appropriately respond to these inflows. Figure 1 shows the trend of International remittances in Ghana from 1979 to 2013.

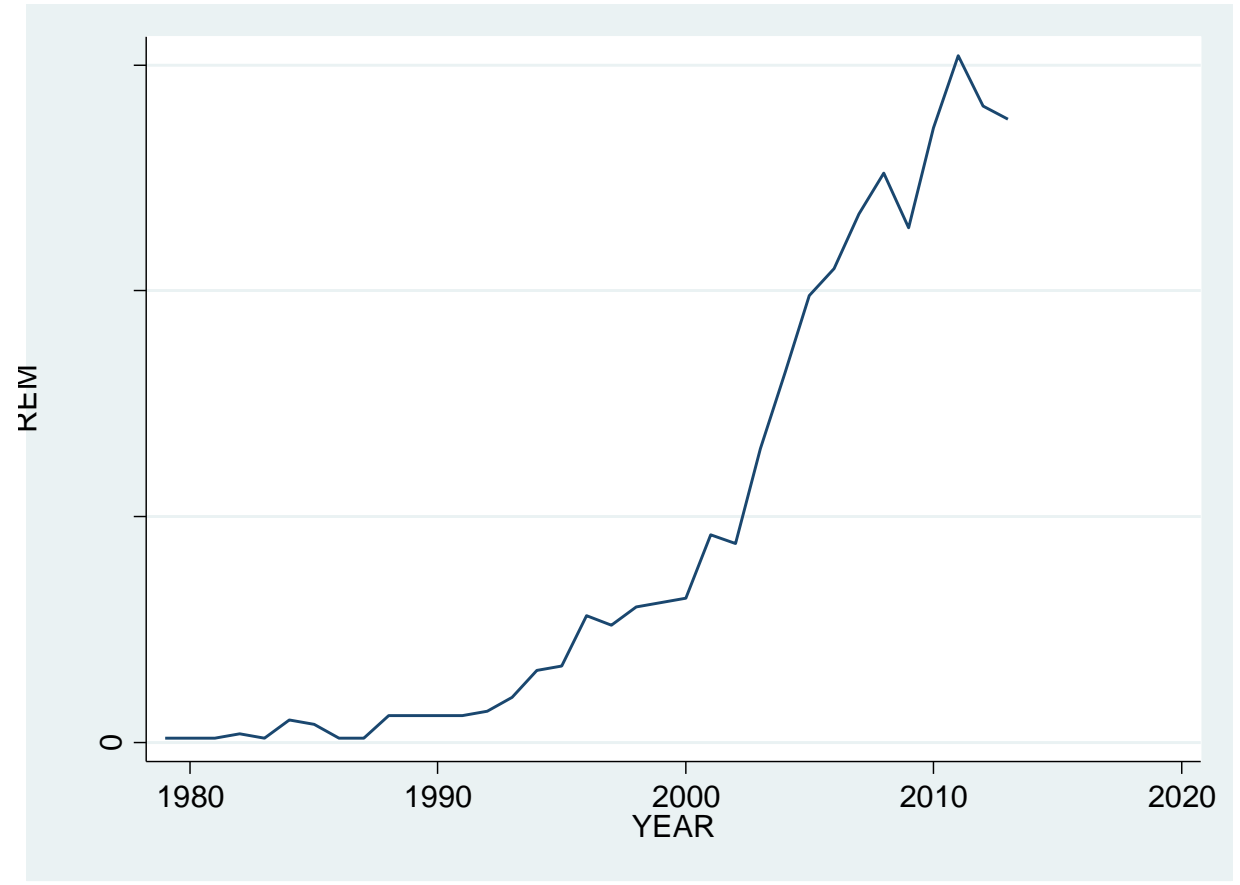

Figure 1. Trend of International Remittances Inflow to Ghana from 1979 -2013 
Source: Migration and Remittances Data, World Bank (2014)

It can be seen from figure 1 that in the period under consideration, the flow of international remittances to Ghana has been remarkable. The figures could even be higher than what the World Bank has captured since some remittances are sent through unapproved routes. Figure 2 shows the trend of inflation rate in the period under review.

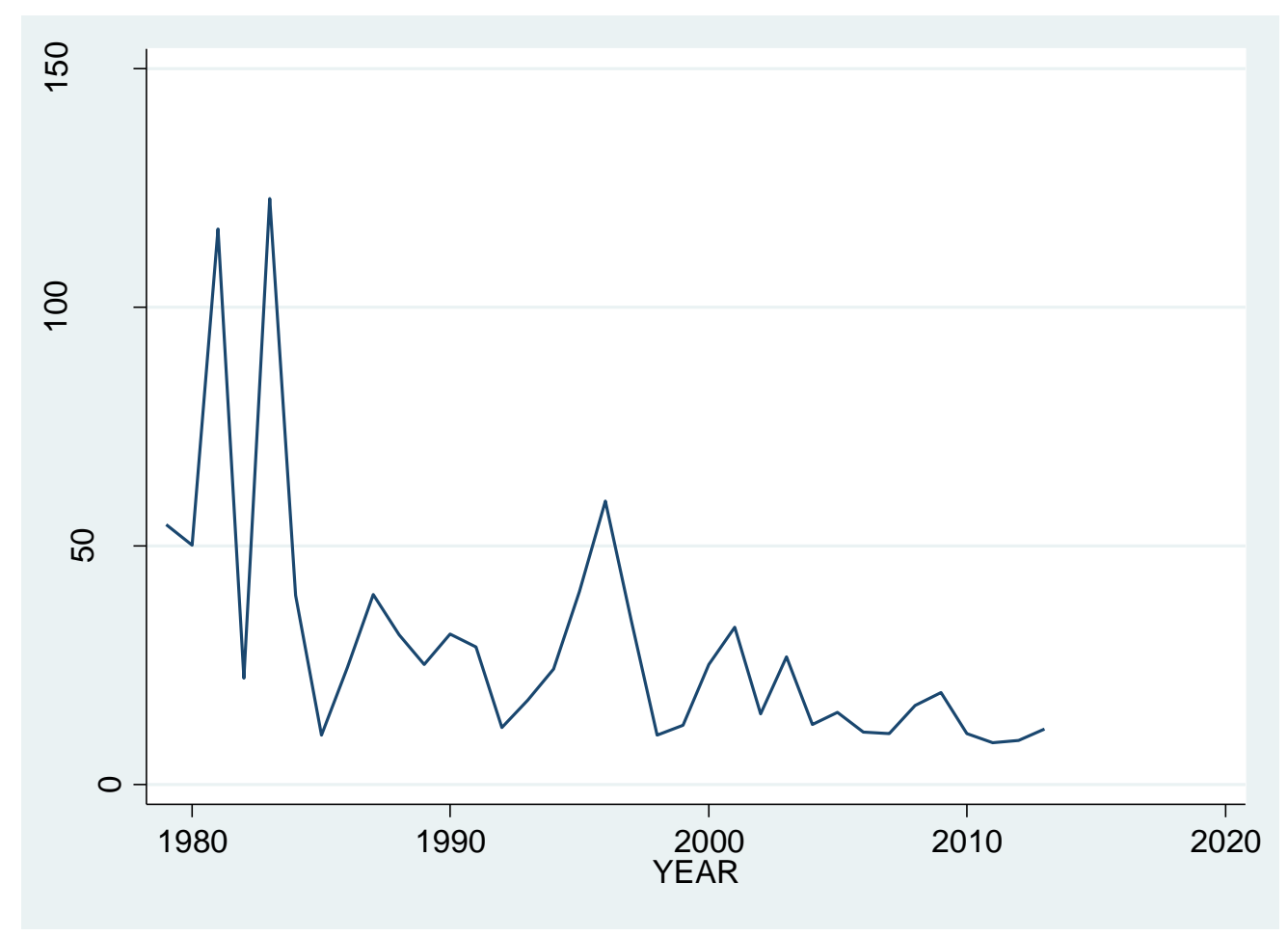

Figure 2. Trend of Annual Inflation Rate in Ghana from 1979 -2013

Source: World Development Indicators, World Bank, (2014)

In figure 2, the trend of inflation rate shows a relative decline over the period under review. This may be due largely to various macroeconomic policies put in place in the country from 1979 to 2013.

\section{Related Literature}

According to Roy and Rahman (2014), remittances can contribute towards foreign reserves accumulation and thus generate a surplus in balance of payment. They state that if the central banks fail to fully sterilize the increase in foreign reserves, it will lead to an increase in monetary base and appreciation of real exchange rate. Thus, there will be a rise in the price level.

Solimano (2003) states that the analytical literature on the motives behind remittances can be summarized in the following four approaches namely; altruistic motive, self-interest motive, implicit family contract 1: loan repayment and implicit family contract II: co-insurance. For the altruistic motive, remitting is considered as an obligation to the household. Migrants send out remittances to the families out of affection and responsibility towards the families. 
Motives by altruism assume that an agent receives utility from an increase in utility of family members left behind.

According to the self-interest motive, at every point in time, the successful migrant saves and so the need then arises on how and where to accumulate wealth. In most cases, the migrant chooses to invest in his home town or country by buying property, financial assets etc. The family then, in turn, acts as a trusted agent by administering those assets for the migrant during the emigration period.

The loan repayment theory states that families tend to develop an implicit contract among those who stay at home. This implicit contract combines elements of investment and repayment. Thus, in the loan repayment theory, the family invests in education of the migrant and usually finances the costs of travel by the migrant to the host town or country. When the migrant starts working and his income profile begins to rise over time, he repays the loan back to the family by sending remittances.

Finally, in the coinsurance theory, migration becomes a co-insurance strategy with remittances playing the role of an insurance claim. For instance, if economic risks between sending and foreign countries are not positively correlated, then the family can send some of its members abroad to diversify economic risks.

\subsection{Empirical Literature Review}

Empirical research on the effect of remittances on inflation is limited and provides mixed results.

According to Balderas and Nath (2008), remittances may have an effect on inflation through their direct and indirect effect on aggregate demand. Applying autoregressive techniques, Khan and Islam, (2013) find that in Bangladesh, a one percent increase in remittances inflows lead to an increase in inflation rate by 2.48 percent in the long run. However, in the short run, no significant relationship exists between these variables. A study by Durand et al., (1996) finds that about three quarters of reported remittances to Mexico are spent on consumption and this in turn, affects inflation rate. Again, using panel dynamic estimator Arellano and Bond (1991) and Arellano and Bover (1995) find that remittances cause an increase in inflation in developing countries and the effect is more pronounced in the long run. Similarly, studies by Amuendo-Dornates and Pozo (2004), Moline and Bussolo (2007), Narayan et al., (2011) show that increase in remittances leads to an increase in inflation rate.

However, Katseli and Glytsos (1986) find that remittances have an inverse relationship with inflation rate in Greece. Similarly, Ball et al., (2013) used a theoretical model and panel vector autoregression techniques to test the relationship between remittances, inflation and exchange rate regimes for 21 emerging countries. Their theoretical model predicts that under a fixed exchange rate regime, remittances temporarily increase domestic money supply and inflation. On the other hand, remittances temporarily generate no change in the money supply, decrease inflation and appreciate the real exchange rate under a flexible exchange rate regime. 
Given the above discussions on the literature, there seems to be space for more research on the effect of remittances on inflation in Ghana.

\section{Data Source and Methodology}

All aggregate annual data are sourced from World Development Indicators (WDI) and the Migration and Remittances data published by the World Bank (2014). Since the number of observations is not large enough for estimating a long-run remittance and inflation model, we resort to the bounds testing procedure, developed by Pesaran et al. (2001). In other words, the use of the bounds testing approach is more appealing than other cointegration methods because it is relatively more robust in small samples. This approach has been widely used in several academic papers some of which include Ahmed et al. (2011), Dogan (2015) and Serker (2015). Following Khan and Islam (2013) and Roy and Rahman (2014) the hypothesized model specification is as follows:

$$
C P I_{t}=f(\mathrm{OPEN}, \mathrm{REM}, \mathrm{MON}, \mathrm{GDP})
$$

Where CPI represents the consumer price index (and used as a proxy for inflation rate), OPEN represents trade openness, REM represents international remittances, MON is broad money (M2) and GDP is the nominal gross domestic product. All the values used for these variables are annual data. Equation (1) can be rewritten as follows:

$$
C P I_{t}=\beta_{0} \mathrm{OPEN}^{\beta_{1}} \mathrm{REM}^{\beta_{2}} \mathrm{MON}^{\beta 3} \mathrm{GDP}^{\beta_{4}} \ell^{\mu_{t}}
$$

Where $\mu_{t}$ is the error term. From equation (2), the specific model for inflation for the Ghanaian economy in a log-linear form is stated as follows:

$$
\ln C P I_{t}=\beta_{0}+\beta_{1} \operatorname{lnOPEN}_{t}+\beta_{2} \operatorname{lnREM}_{t}+\beta_{3} \operatorname{lnMON}_{t}+\beta_{4} \operatorname{lnGDP}_{t}+\mu_{t}
$$

Where $\beta_{i}$ represents the elasticity coefficients. The choice of the log-linear model was because of the following reasons: Firstly, to find the percentage change in the dependent variable resulting from percentage changes in the independent variables. Thus, the study sought to find the responsiveness of a change in inflation to changes in trade openness, international remittances, money supply and GDP. Secondly, the use of log transformation is necessary because it compresses the scale in which the variables are measured, reducing a tenfold difference between two values to a twofold difference. This reduces the possibility of heteroskedasticity in the model (Gujarati, 1995, p421).

\subsection{Variance Inflation Factor (VIF) Test}

A VIF test was carried out to establish the existence of multicollinearity among all the explanatory variables in the model. According to Gujarati and Porter (2009), in cases of near or high multicollinearity, the OLS estimators have large variances and covariances, making 
precise estimation difficult.

\subsection{Unit Root Test}

The Phillip and Perron (herein after PP) and the Augmented Dickey-Fuller (ADF) tests were used to test the stationary status of the variables used in the equation. However, the PP test is preferred to the traditional Augmented Dickey-Fuller (ADF) test because of its use of non-parametric methods to adjust for serial correlation and endogeneity of regressors thereby preventing the loss of observations implied by the ADF test. The presence of unit root in the series indicates that the variable is non-stationary, hence the degree or order of integration is one or higher. The absence of unit root, however, implies that the variables are stationary and the order of integration is zero.

\subsection{ARDL Model Specification}

This section summarizes the autoregressive distributed lag (ARDL) model, or bounds testing approach (Pesaran et al., 2001), which is used in this study to check the existence of short and long-run relationships between inflation rate, trade openness, international remittances and money supply in the case of Ghana.

The use of the bounds testing technique is based on three reasons. First, Pesaran et al. (2001) advocated the use of the ARDL model for the estimation of level relationships because the model suggests that once the order of the ARDL has been recognized, the relationship can be estimated by OLS. Secondly, the bounds test allows a mixture of I(1) and I(0) variables as regressors. That is, the order of integration of appropriate variables may not necessarily be the same. Therefore, the ARDL technique has the advantage of not requiring a specific identification of the order of integration of the underlying data. Thirdly, this technique is suitable for small or finite sample size (Pesaran et al., 2001).

Following Pesaran et al. (2001), we assemble the vector autoregression (VAR) of order $p$, denoted VAR $(p)$, for the following inflation function:

$$
Z_{t}=\beta_{0}+\alpha_{t}+\sum_{i=1}^{p} \phi_{i} z_{t-i}+\varepsilon_{t} \quad \mathrm{t}=1,2,3,4 . \mathrm{T}
$$

Where $Z_{t}$ is a vector of both $\pi_{t}$ and $x_{t} \cdot \pi_{t}$ is the dependent variable and represents inflation rate. $x_{t}$ is the vector matrix and represents a set of explanatory variables while $t$ is a time or trend variable. $\beta_{0}$ represents $(\mathrm{k}+1)$ - a vector of intercept (drift) and $\alpha_{t}$ represents $(\mathrm{k}+1)-\mathrm{a}$ vector of trend coefficients.

According to Pesaran et al. (2001), $\pi_{t}$ must be of order I(1). However, $x_{t}$ can be either $\mathrm{I}(0)$ or I(1). In addition, a vector error correction model (VECM) is developed as follows: 


$$
\Delta z_{t}=\mu+\beta_{0}+\lambda z_{t-i}+\sum_{i=1}^{p-i} \gamma_{i} \Delta \pi_{t-i}+\sum_{i=1}^{p-i} \gamma_{i} \Delta x_{t-i}+\varepsilon_{t} \mathrm{t}=1,2,3,4 \mathrm{~T}
$$

Where $\Delta$ is the difference operator and the long run multiplier matrix is stated as follows:

$$
\lambda=\left[\begin{array}{ll}
\lambda \pi \pi & \lambda \pi x \\
\lambda x \pi & \lambda x x
\end{array}\right]
$$

The diagonal elements of the matrix are unrestricted, so the selected series can be either I(0) or I(1). If $\lambda \pi \pi=0$, then $\pi=\mathrm{I}(1)$. On the other hand, if $\lambda \pi \pi<0$, then $\pi=I(0)$. The VECM procedures described previously are imperative in the testing of at most one cointegrating vector between the dependent variable $\pi_{t}$ and a set of regressors $x_{t}$. After imposing the restriction $\lambda \pi \pi=0, \mu \neq 0$, and $\alpha=0$, the international remittances-inflation nexus can be stated as the following unrestricted error correction model (UECM):

$$
\begin{aligned}
& \Delta(\operatorname{lnCPI})_{t}=\beta_{0}+\beta_{1}(\operatorname{lnCPI})_{t-i}+\beta_{2}(\operatorname{lnOPEN})_{t-i}+\beta_{3}(\operatorname{lnREM})_{t-i}+\beta_{4}(\operatorname{lnMON})_{t-i}+\beta_{5}(\operatorname{lnGDP})_{t-i} \\
& +\sum_{i=1}^{p} \beta_{1 i} \Delta(\operatorname{lnCPI})_{t-i}+\sum_{j=1}^{q} \beta_{2 j} \Delta(\operatorname{lnOPEN})_{t-j}+\sum_{k=1}^{q} \beta_{3 k} \Delta(\operatorname{lnREM})_{t-k}+ \\
& \sum_{m=1}^{q} \beta_{4 m} \Delta(\operatorname{lnMON})_{t-m}+\sum_{n=1}^{q} \beta_{5 n} \Delta(\operatorname{lnGDP})_{t-n}+\mu_{t}
\end{aligned}
$$

Where $\Delta$ represents the first difference operator and $\mu_{t}$ is the white noise disturbance term. Equation (6) shows that inflation rate is influenced and explained by its past values. After carrying out the regression of equation (6) the F-Wald test was done in order to differentiate the long run relationship between the concerned variables. This was done by imposing restrictions on the estimated long run coefficients of the consumer price index, trade openness, international remittances, money supply and GDP. The null and alternative hypotheses are as follows:

$H_{0}: \beta_{0}=\beta_{1}=\beta_{2}=\beta_{3}=\beta_{4}=0$ against the alternative hypothesis

$\beta_{0} \neq \beta_{1} \neq \beta_{2} \neq \beta_{3} \neq \beta_{4} \neq 0$ (Long run relationship exists)

The test which normalizes on $C P I$ is denoted by

$F_{C P I}(C P I \mid$ OPEN, REM, MON, GDP)

Two asymptotic critical values provide a test for cointegration when the independent 
variables are $\mathrm{I}(\mathrm{d})$ (where $0 \leq d \leq 1$ ): a lower value assuming the regressors are $\mathrm{I}(0)$ and an upper value assuming purely I(1) regressors. If the F-statistic is above the upper critical value, the null hypothesis of no long-run relationship is rejected regardless of the orders of integration for the time series. This implies that there is long run relationship among the series. On the other hand, if the F-statistic is less than the critical value, we fail to reject the null hypothesis and this implies that there is no long-run relationship among the series. Lastly, if the F-statistic falls between the lower and the upper critical values, the result is inconclusive.

In the second stage of the bounds testing approach, after establishing cointegration, the conditional ARDL ( $p, q 1, q 2, q 3, q 4)$, the long-run model for $C P I_{t}$ was estimated as:

$$
\operatorname{lnCPI}_{t}=\beta_{0}+\sum_{i=1}^{p} \beta_{1} \operatorname{lnCPI}_{t-1}+\sum_{i=0}^{q 1} \beta_{2} \operatorname{lnOPEN}_{t-1}+\sum_{i=0}^{q 2} \beta_{3} \operatorname{lnREM}_{t-1}+\sum_{i=0}^{q 3} \beta_{4} \operatorname{lnMON}_{t-1}+\sum_{i=0}^{q 4} \beta_{5} \operatorname{lnGDP}_{t-1}+\mu_{t}
$$

This involves selecting the orders of the $\operatorname{ARDL}(p, q 1, q 2, q 3, q 4)$ model in the four variables using Schwartz Bayesian Criterion.

Finally, an Error Correction Model (ECM) was estimated to capture short-run dynamics of the system. Generally, the ECM provides the means of reconciling the short-run behaviour of an economic variable with its long-run behavior. The ECM is specified as follows:

$$
\begin{aligned}
& \Delta \operatorname{lnCPI} t=\beta_{0}+\sum_{i=1}^{p} \beta_{1 i} \Delta \operatorname{lnCPI}_{t-1}+\sum_{i=0}^{q 1} \beta_{2 j} \Delta \operatorname{lnOPEN}_{t-1}+\sum_{i=0}^{q 2} \beta_{3 k} \Delta \operatorname{lnREM}_{t-1}+\sum_{i=0}^{q 3} \beta_{4 m} \Delta \operatorname{lnMON}_{t-1} \\
& +\sum_{i=0}^{q 4} \beta_{5 n} \Delta \operatorname{lnGDP}_{t-1}+\rho E C M_{t-1}+\mu_{t}
\end{aligned}
$$

From equation (8), the betas represent the short-run dynamics coefficients of the model's convergence to equilibrium. $E C M_{t-1}$ is the Error Correction Model. The coefficient of the Error Correction Model, $\rho$ measures the speed of adjustment to obtain equilibrium in the event of shocks to the system.

\section{Results and Discussion}

In order to examine the effect of international remittances on inflation in Ghana, the stationarity status of all the variables specified in the model for the study were determined. The presence of unit root in macroeconomic time series has an important economic 
implication that a shock to the variable tends to have a permanent effect. Regressions with non-stationary data have high potential of leading to spurious relationship and hence wrong inference between or among macroeconomic variables. It is therefore a necessary first-step to examine the order of integration of the relevant variables used in this study. The Phillips-Perron (PP) test was therefore conducted and the results are presented in table 1.

Table 1. Phillips-Perron Unit Root Test Results

\begin{tabular}{|l|l|l|l|l|l|}
\hline & \multicolumn{6}{|c|}{ Phillips-Perron Test Statistic } \\
\hline Variable & $\begin{array}{l}\text { Test Statistic } \\
\text { Value }\end{array}$ & $\begin{array}{l}\text { Critical t value at } \\
1 \%\end{array}$ & $\begin{array}{l}\text { Critical t value at } \\
5 \%\end{array}$ & $\begin{array}{l}\text { Critical t value at } \\
10 \%\end{array}$ & $\begin{array}{l}\text { P- } \\
\text { value }\end{array}$ \\
\hline LnCPI & $-4.823 * * *$ & -3.689 & -2.975 & -2.619 & 0.0000 \\
\hline InOPEN & -1.119 & -3.689 & -2.975 & -2.619 & 0.7075 \\
\hline$\triangle \ln O P E N$ & $-3.867 * * *$ & -3.696 & -2.978 & -2.620 & 0.0023 \\
\hline LnREM & -1.175 & -3.689 & -2.975 & -2.619 & 0.6844 \\
\hline$\triangle \ln R E M$ & $-6.975 * * *$ & -3.696 & -2.978 & -2.620 & 0.0000 \\
\hline LnMON & -2.491 & -3.689 & -2.975 & -2.619 & 0.1178 \\
\hline$\triangle \ln M O N$ & $-4.517 * * *$ & -3.696 & -2.978 & -2.620 & 0.0002 \\
\hline LnGDP & -2.632 & -3.689 & -2.975 & -2.619 & 0.0868 \\
\hline$\triangle \ln G D P$ & $-5.844^{* * * *}$ & -3.696 & -2.978 & -2.620 & 0.0000 \\
\hline
\end{tabular}

Unit root tests were performed in Stata 13. ***,**,* indicate the rejection of the null hypothesis of unit root at $1 \%, 5 \%$ and $10 \%$ level of statistical significance respectively.

As it can be seen from table 1, at levels all the variables (except lnCPI) are not stationary which implies that the null hypothesis of unit root is accepted. However, after taking the first difference, all the variables became stationary.

To reaffirm that the series were stationary, the augmented dickey fuller (ADF) test was also carried out and the results are as follows:

Table 2. Augmented Dickey Fuller (ADF) Test Unit Root Results

\begin{tabular}{|l|l|l|l|l|l|}
\hline & \multicolumn{5}{|c|}{ ADF Test Statistic } \\
\hline & Test Statistic & $\begin{array}{l}\text { Critical t value at } \\
1 \%\end{array}$ & $\begin{array}{l}\text { Critical t value at } \\
5 \%\end{array}$ & $\begin{array}{l}\text { Critical t value at } \\
10 \%\end{array}$ & $\begin{array}{l}\text { P- } \\
\text { value }\end{array}$ \\
\hline VnCPI & $-4.823^{* * *}$ & -3.689 & -2.975 & -2.619 & 0.0000 \\
\hline $\ln O P E N$ & -1.119 & -3.689 & -2.975 & -2.619 & 0.7075 \\
\hline$\triangle \ln O P E N$ & $-3.809 * * *$ & -3.696 & -2.978 & -2.620 & 0.0023 \\
\hline LnREM & -1.175 & -3.689 & -2.975 & -2.619 & 0.6844 \\
\hline$\triangle \ln R E M$ & $-7.065^{* * *}$ & -3.696 & -2.978 & -2.620 & 0.0000 \\
\hline LnMON & -2.491 & -3.689 & -2.975 & -2.619 & 0.1178 \\
\hline$\triangle \ln M O N$ & $-5.558^{* * *}$ & -3.696 & -2.978 & -2.620 & 0.0002 \\
\hline LnGDP & -2.632 & -3.689 & -2.975 & -2.619 & 0.0868 \\
\hline$\triangle \ln G D P$ & $-6.624 * * *$ & -3.696 & -2.978 & -2.620 & 0.0000 \\
\hline
\end{tabular}


Unit root tests were performed in Stata $13.0 * * *, * *, *$ indicate the rejection of the null hypothesis of unit root at $1 \%, 5 \%$ and $10 \%$ level of statistical significance respectively.

\subsection{Results of the Bounds Test for Cointegration}

As a first step of the ARDL approach the conditional VECM by ordinary least square was estimated in order to test for the presence of long run relationship among the variables. This was done by conducting an F-test for the joint significance of the coefficients of the variables. The results of the computed F-statistic when each variable is normalised (that is, considered as a dependent variable) in the ARDL-OLS regressions are presented in table 3.

Table 3. Testing for existence of cointegration among the variables in the ARDL model

\begin{tabular}{|l|l|l|l|l|l|l|}
\hline F-Statistic & $\begin{array}{l}99 \% \text { Lower } \\
\text { Bound }\end{array}$ & $\begin{array}{l}99 \% \text { Upper } \\
\text { Bound }\end{array}$ & $\begin{array}{l}95 \% \text { Lower } \\
\text { Bound }\end{array}$ & $\begin{array}{l}95 \% \text { Upper } \\
\text { Bound }\end{array}$ & $\begin{array}{l}90 \% \text { Lower } \\
\text { Bound }\end{array}$ & $\begin{array}{l}90 \% \text { Upper } \\
\text { Bound }\end{array}$ \\
\hline & & & & & & 2.45 \\
\hline 8.275 & 3.74 & 5.06 & 2.86 & 4.01 & 3.52 \\
\hline
\end{tabular}

Results were obtained from Microfit 5.0.

From table 3, it can be seen that the computed F-statistic of 8.275 is greater than the upper bound at $1 \%, 5 \%$ and $10 \%$ levels of significance. In other words, the estimated F-statistic is greater than the upper bound critical values even at the $1 \%$ level. As a result, it can be concluded that there exists a strong long run equilibrium relationship among the variables.

Table 4. Estimated Long Run Coefficients using the ARDL Approach

ARDL $(1,1,0,1,1)$ selected based on Schwarz Bayesian Criterion

Dependent variable is LNCPI

33 observations used for estimation from 1981 to 2013

\begin{tabular}{|c|c|c|c|c|}
\hline 'Regressor & Coefficient & Standard Error & T-Ratio & Prob \\
\hline LNOPEN & $0.36475^{* * *}$ & 0.11162 & 3.2677 & 0.003 \\
\hline LNREM & $0.16597^{*}$ & 0.092954 & 1.7855 & 0.087 \\
\hline LNMON & $1.0281 * * *$ & 0.36706 & 2.8009 & 0.010 \\
\hline LNGDP & -0.59742 & 0.39091 & -1.5283 & 0.140 \\
\hline CONSTANT & -9.4388 & 1.8089 & -5.2179 & 0.000 \\
\hline \multicolumn{5}{|c|}{$\begin{array}{l}* * *, * * \text {, and } * \text { denote the rejection of the null hypotheses at } 1 \%, 5 \% \text { and } 10 \% \text { levels of significance. Results } \\
\text { were obtained from Microfit } 5.0\end{array}$} \\
\hline
\end{tabular}

The results from table 4 show that the effect of trade openness on inflation is positive and statistically significant at $1 \%$. The estimates indicate that all other factors held constant, in the long run, a 1 percent increase in trade openness will lead to an increase in inflation rate by 0.37 percent. This may be as a result of Ghana's high import bill per annum. A coefficient of approximately 0.16597 for international remittances means that all other things being equal, a 1 percent increase in international remittances will lead to an increase in inflation rate by 
about $0.17 \%$ and this statistically significant at $10 \%$. The implication of this result is that a greater amount of the remittances by migrants into the country are mainly used for consumption purposes rather than for investment on productive activities. This finding is consistent with that of Amuendo-Dornates and Pozo (2004), Bashir et al. (2011) and Khan and Aslam (2013). Again, a coefficient of 1.0281 for money supply implies that a 1 percent increase in money supply will lead to an increase in inflation rate by about 1.03 percent at $1 \%$ significance level and this is consistent with the monetarist view that states that inflation is caused by increase in money supply. Finally, a coefficient of -0.59742 for GDP indicates that holding other factors constant, a 1 percent increase in GDP will lead to a decrease in inflation rate by about 0.6 percent. This result is, however, not statistically significant. An increase in GDP means that there has been an increase in the value of output produced by the macroeconomic sectors of the economy and this will lead to a decrease in the rate of inflation.

Table 5. Diagnostic Tests Results

\begin{tabular}{|l|l|l|}
\hline Test Statistic & LM VERSION & F VERSION \\
\hline A. Serial Correlation & CHSQ $(1)=1.2569[0.262]$ & $\mathrm{F}(\quad 1, \quad 23)=.91068[.350]$ \\
\hline B. Functional Form & CHSQ $(1)=2.5840[0.108]$ & $\mathrm{F}(\quad 1, \quad 23)=1.9540[.175]$ \\
\hline C. Normality & $\mathrm{CHSQ}(2)=1.6863[0.430]$ & Not applicable \\
\hline D:Heteroskedasticity & $\mathrm{CHSQ}(1)=.0054636[.941]$ & $\mathrm{F}(\quad 1, \quad 31)=.0051333[.943]$ \\
\hline \multicolumn{3}{|l}{} \\
\hline
\end{tabular}

A: Lagrange multiplier test of residual serial correlation

B: Ramsey's RESET test using the square of the fitted values

C: Based on a test of skewness and kurtosis of residuals

D: Based on the regression of squared residuals on squared fitted values

The results of the diagnostic tests in table 5 disclosed that the model has the aspiration of econometric properties. They demonstrate that the model is has no serial correlation and heteroskedasticity. The functional form is up to mark and normality assumption is also satisfied.

A variance inflation factor test was also carried out and the result is shown in table 6 .

Table 6. Variance Inflation Factor Test

\begin{tabular}{|l|l|l|}
\hline Variable & VIF & $1 /$ VIF \\
\hline LNMON & 15.44 & 0.064766 \\
\hline LNGDP & 19.24 & 0.051975 \\
\hline LNREM & 9.70 & 0.103092 \\
\hline LNOPEN & 3.75 & 0.266542 \\
\hline Mean VIF & 12.03 & \\
\hline
\end{tabular}

VIF test was performed in Stata 13 
In table 6, the variable of interest LNREM shows a VIF of 9.70. It must be noted that the variables with high VIFs are control variables and not the variables of interest. Multicollinearity can therefore be safely ignored. The "do nothing" school of thought expressed by Blanchard (1967) states that "multicollinearity is God's will and not a problem with OLS or statistical technique in general. He argues that multicollinearity is essentially a data deficiency problem and sometimes we have no choice over the data we have available for empirical analysis (Gujarati \& Porter, 2009, pp. 342).

Table 7. Error Correction Representation for the Selected ARDL Model

ARDL $(1,1,0,1,1)$ selected based on Schwarz Bayesian Criterion

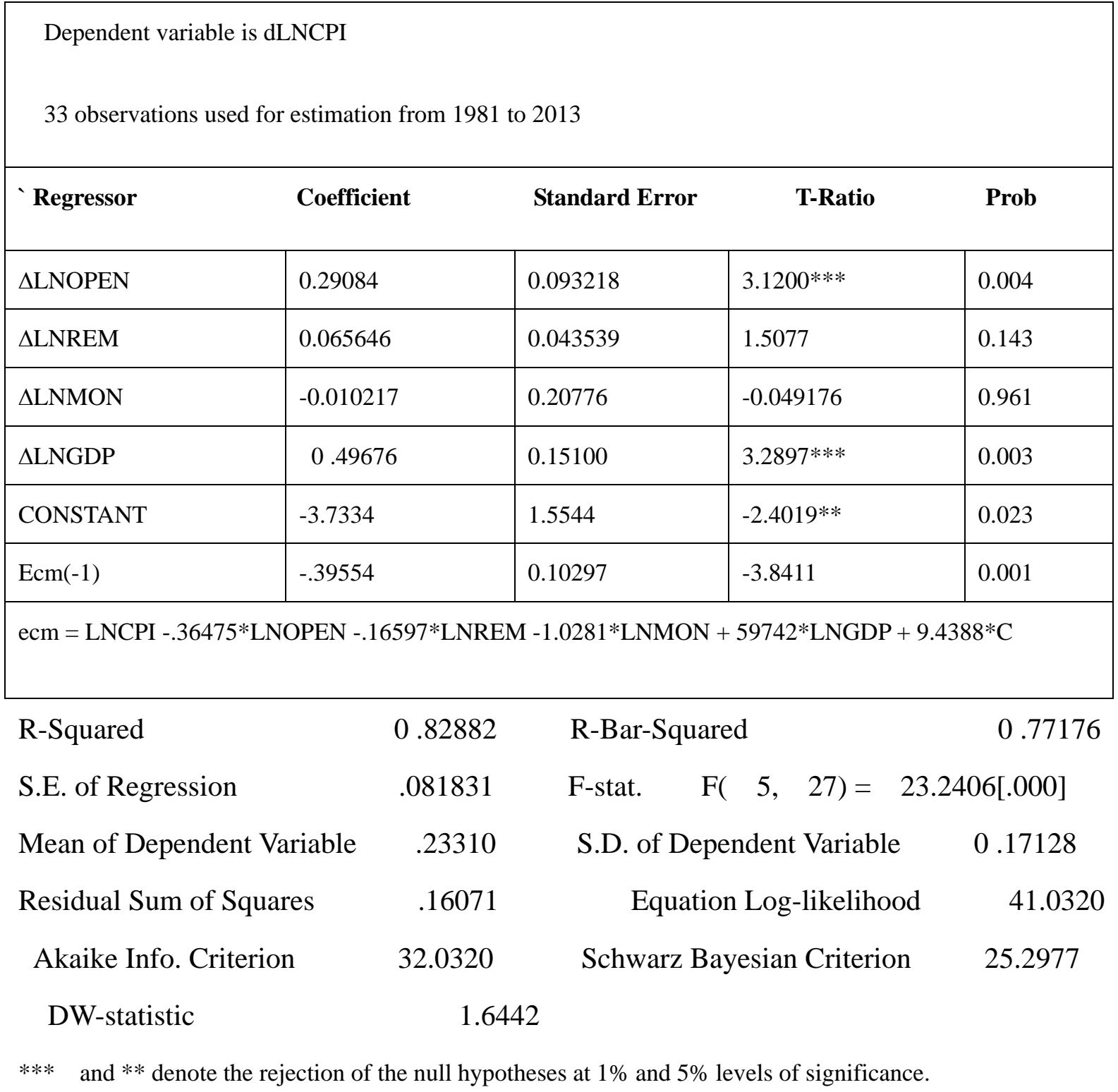

The adjusted R-squared value of 0.77 indicates that about $77 \%$ of the changes in inflation rate are explained by changes in the independent variables. The regression model is said to be significant both at $1 \%$ and $5 \%$ following the F-statistic of 23.24. The empirical findings from the error-correction model show that inflation rate adjusts towards long run equilibrium at the 


\section{Macrothink}

Business and Economic Research ISSN 2162-4860 2016, Vol. 6, No. 1

speed of about $40 \%$. A coefficient of 0.29 for trade openness indicates that all other factors remaining constant, in the short-run, a 1 percent increase in trade openness will lead to an increase in inflation rate by 0.29 percent and statistically significant at $1 \%$. This may be due to the fact that Ghana pays more for its imports than it earns on its exports which are mainly primary commodities. A coefficient of approximately 0.066 for international remittances means that in the short run, a 1 percent increase in international remittances will lead to an increase in inflation rate by about $0.07 \%$ all other factors remaining the same. This result, however, is statistically insignificant. Again, the results show that in the short run, a 1 percent increase in money supply will lead to a decrease in inflation rate by about 0.01 percent all other factors being equal. Again, this is statistically insignificant. Finally, in the short run, GDP has a positive influence on the rate of inflation and statistically significant at $1 \%$ level. The results show that all things being equal, in the short run, a 1 percent increase in GDP will lead to an increase in inflation rate by about 0.5 percent.

\section{Plot of Cumulative Sum of Recursive Residuals}

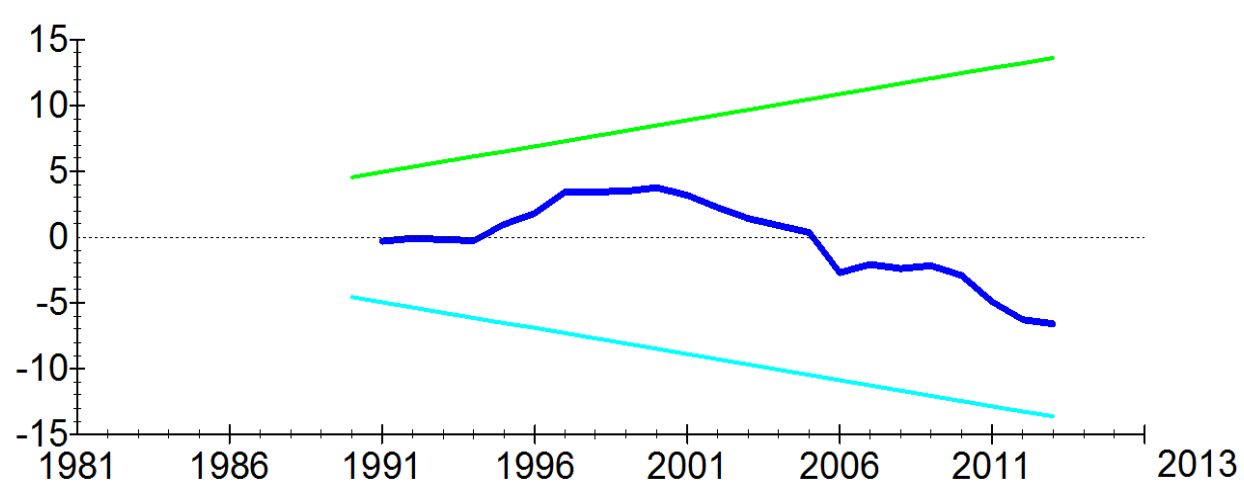

The straight lines represent critical bounds at $5 \%$ significance level

Figure 3. Plot of Cumulative Sum of Recursive Residuals (CUSUM)

\section{Plot of Cumulative Sum of Squares of Recursive Residuals}

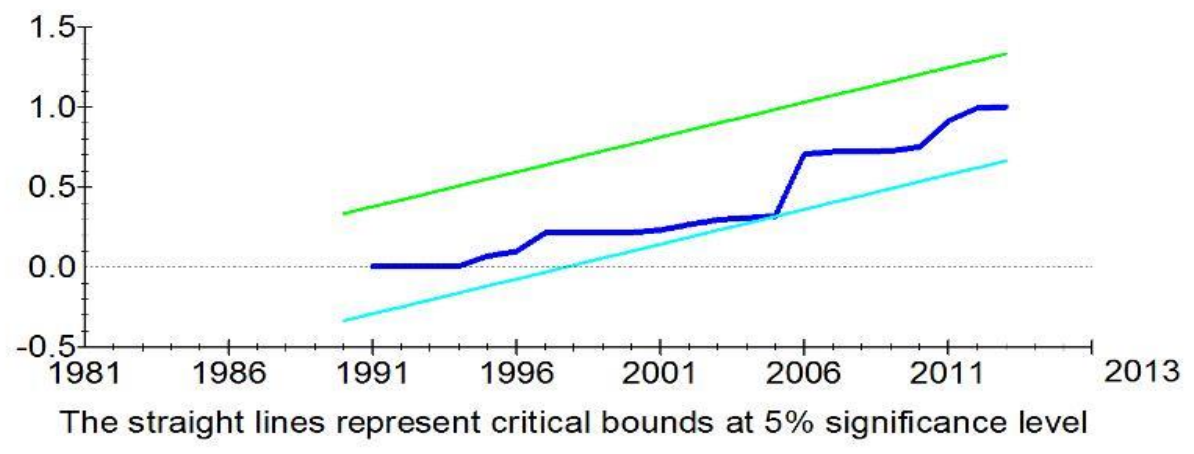


Figure 4. Plot of Cumulative Sum of Squares of Recursive Residuals (CUSUMSQ)

Source: Author, 2015

Figures 3 and 4 show that both CUSUM and CUSUMQ are within the critical bounds and this implies that the model is structurally stable.

\section{Conclusion}

The study examined the long run and short run relationships among inflation rate, trade openness, international remittances, money supply and GDP using the bounds testing approach. The results from the error-correction model show that the inflation adjusts slowly to its equilibrium. However, empirical findings show that in the long- run, inflation rate is positively related to trade openness, international remittances and money supply but negatively related to GDP. The consumption pattern of the recipients in Ghana may be the reason why international remittances play a major role in increasing inflation in the long run.

\section{Policy Implications/Recommendations}

The findings are of major significance for policy makers who seek to attract international remittances in order to encourage investment in the country and increase economic growth. One possible interpretation of our results is that an increase in international remittances, trade openness and money supply in Ghana will lead to an increase in inflation rate in the long run. This will in turn increase the cost of living in the country. Again, the fact that international remittances have a positive and significant effect on inflation implies that much of the remittances are used by recipients to purchase consumer goods in the country. In view of this, the study recommends that the government should formulate policies aimed at channeling the remittances for productive economic activities rather than for consumption. This could be done by improving public infrastructure and investment in education. Furthermore, government policy should be directed at encouraging savings that would boost private investment and economic growth. Finally, there should be mechanisms aimed at mobilizing remittances for investment through higher interest rates on term deposits, foreign currency denominated banking accounts, and tax incentives.

\section{References}

Adenutsi, E. D. (2011). Financial development, international remittances and endogenous growth in Ghana. Studies in Economics and Finance, 28(1), http://dx.doi.org/10.1108/10867371111110561

Ahmed J, Khalid Z., \& Iqtidar A. S. (2011). An empirical analysis of remittances-growth nexus in Pakistan using bounds testing approach. Journal of Economics and International Finance, 3(3), 176-186, March 2011. Retrieved from http://www.academicjournals.org/JEIF

Arellano, M., \& Bond, S. (1991). Some tests of specification for panel data: monte carlo evidence and an application to employment equations. The Review of Economic Studies. http://dx.doi.org/10.2307/2297968.

Arellano, M., \& Bover, O. (1995). Another look at the instrumental variable estimation of 
error correction models. Journal of Econometrics. http://dx.doi.org/10.1016/0304-4076(94)01642-D

Balderas J. U. \& Nath H. K., (2008). Inflation and relative price variability in Mexico: the role of remittances. Applied Economics Letters, 15, 181-185. http://dx.doi.org/10.1080/13504850600722070

Ball, C., Lopez, C., \& Reyes, J. (2013). Remittances, inflation and exchange rate regimes in small open economies. The World Economy. Retrieved from http://onlinelibrary.wiley.com/doi/10.1111/twec.12042/full.

Bashir M. F., Nawaz, M. S., Yasin, M. K., Khursheed, M. U., Khan, M. J., \& Qureshi, M. M. J. (2011). Determinants of inflation in Pakistan: An econometric analysis using Johansen co-integration approach. Australian Journal of Business and Management Research, 1(5), 71-82.

Blankard, O. J., (1967). Comment, Journal of Business and Economic Statistics, 5, 449-451.

Blundell, R., \& Bond, S., (1997). Initial Conditions and Moment Restrictions in Dynamic Panel Data Models, Discussion Papers No. 97-07, pp. 1-40, (London, United Kingdom: University College London).

Clemens, M., (2007). Do visas kill? Health effects of African professional emigration, CGD Working Paper No. 114. Washington, DC: Center for Global Development.

Dogan, E. (2015). The relationship between economic growth and electricity consumption from renewable and non-renewable sources: A study of Turkey. Renewable and Sustainable Energy Reviews, 52, 534-546. http://dx.doi.org/10.1016/j.rser.2015.07.130

Durand, J., Kandel, W., Parrado, E. A., \& Massey, D. S. (1996). International migration and development in Mexican communities. Demography, 33(2), 249-64. http://dx.doi.org/10.2307/2061875

Gyimah-Brempong, K., \& Asiedu, E., (2014). Remittances and investment in education: evidence from Ghana, Journal of International Trade \& Economic Development: An International and Comparative Review. http://dx.doi.org/10.1080/09638199.2014.881907

Gujarati, D. N., (1995). Basic Econometrics, 3rd Edition. New York: McGraw-Hill, 1995. ISBN 0-07-025214-9.

Gujarati, D. N., \& Porter, D. C., (2009). Basic Econometrics, 5rd Edition. New York: McGraw-Hill.

Iqbal, Z. \& Abdus S. (2005). The contribution of workers' remittances to economic growth in Pakistan, Research Report No: 187, PIDE, Pakistan.

Javaid, S. H. (2009). Dutch disease investigated: empirical evidence from selected South East Asian economies, Working Paper Series No: 31, State Bank of Pakistan. 


\section{Macrothink}

Business and Economic Research ISSN 2162-4860 2016, Vol. 6, No. 1

Katseli, L. \& Glytsos, N., (1986). Theoretical and empirical determinants of international labour mobility: A Greek-German perspective, Centre for Economic Policy Research Working Paper 148.

Khan, Z., \& Islam, S. (2013). The effects of remittances on inflation: evidence from Bangladesh. Journal of Economics and Business Research. Retrieved from http://www.uav.ro/jour/index.php/jebr/article/view/94

Nishat, M., \& Nighat B. (1991). The impact of migrant worker's remittances on Pakistan economy, Pakistan Economic and Social Review, 29(1), 21-41.

Owiafe, Gloria (2008). The impact of external remittances on poverty reduction in Ghana, Master thesis, Kwame Nkrumah University of Science and Technology.

Pesaran, H., Shin, Y., \& Smith, R. (2001). Bounds testing approaches to the analysis of level relationships. Journal of Applied Econometrics, 16(3), 289-326. http://dx.doi.org/10.1002/jae.616

Quartey, P. (2006). The Impact of Migrant remittances on household welfare in Ghana AERC Research Paper 158, African Economic Consortium, Nairobi.

Ratha, D. (2007). Leveraging Remittances for Development, Migration Policy Institute, Washington, DC. Paper presented at the Second Plenary Meeting of the Leading Group on Solidarity Levies to Fund Development, Oslo, February 6-7, 2007

Ratha, D., Mohapatra, S., \& Silwal, A. (2010). Migration and Development Brief \#12. World Bank.

Roy, R \& Rahman, M.M., (2014). An empirical analysis of remittance -inflation relationship in Bangladesh: post-floating exchange rate. Retrieved from http://mpra.ub.uni-muenchen.de/55190.pdf

Sander C (2003). Migrant Remittances to Developing Countries: A Scoping Study, A Paper Prepared for DFID, Bannock Consulting, June.

Seker, F., Ertugrul, H. M., \& Cetin, M. (2015). The impact of foreign direct investment on environmental quality: A bounds testing and causality analysis for Turkey. Renewable and Sustainable Energy Reviews, 52, 347-356. http://dx.doi.org/10.1016/j.rser.2015.07.118

World Bank (2014). Migration and Remittances Factbook, 2014 World Bank, Washington, DC.

World Bank (2014). Migration and Remittances Factbook 2014, World Bank, Washington, DC.

World Bank (2014). World Development Indicators, 2014, World Bank, Washington, DC.

\section{Copyright Disclaimer}

Copyright for this article is retained by the author(s), with first publication rights granted to the journal. 
This is an open-access article distributed under the terms and conditions of the Creative Commons Attribution license (http://creativecommons.org/licenses/by/3.0/). 